\title{
PROTHROMBOTIC GENE MUTATIONS IN YOUNG PATIENTS WITH ISCHEMIC STROKE: OUR CLINICAL EXPERIENCE
}

\author{
Zeynep ÖZÖZEN AYAS*, Aslı AKSOY GÜNDOĞDU**, Ayhan BÖLÜK*** \\ *Eskișehir City Hospital, Department of Neurology, Eskișehir, TURKEY \\ **Namık Kemal University Faculty of Medical, Department of Neurology, Tekirdağ, TURKEY \\ ***Sakarya University Training and Research Hospital, Department of Neurology, Sakarya, TURKEY
}

\begin{abstract}
INTRODUCTION: Etiological evaluation of stroke in young patient includes different tests. It is important to determine the cause of stroke to plan treatment according to the etiological investigations and to reduce the risk of recurrence. We aimed to investigate the prothrombotic gene mutations in young patients with stroke and to compare the presence and absence of predisposing risk factors in terms of gene mutations.

METHODS: Patients aged 18-45 years with ischemic stroke were included. Protein C (PC), protein S (PS), antithrombin3 (ATIII), homocysteine, antinuclear antibody (ANA) anticardiolipin (ACA) tests and Factor V G1691A Leiden (FVL) genetic test results of prothrombin G20210A, methylenetetrahydrofolate reductase (MTHFR) C677T and A1298C were recorded.

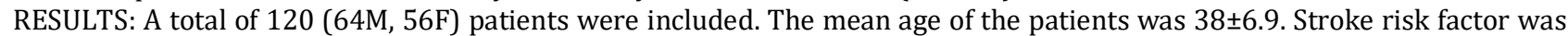
determined in 77 patients and 43 were not detected. Smoking was the most common in $44(36.7 \%)$ and hypertension was recorded in $23(19.2 \%)$ patients. FVL polymorphism was heterozygous in 13 patients. Prothrombin polymorphism 11 heterozygous, 1 homozygous, MTHFRC677T 56 heterozygous, 10 homozygous, MTHFRA1298C polymorphism 45 heterozygote, 13 homozygous was detected. Hyperhomocysteinemia 66, ATIII deficiency 16, PC deficiency 19, PS deficiency was detected in 19 patients. There were no significant differences in the heterozygous and homozygous polymorphisms of the prothrombotic gene in the group with and without predisposing risk factors. In addition, frequency of hyperhomocysteinemia, frequency of ATIII, PC, PS deficiency and frequency of ANA positivity were not significantly different between these two groups.

DISCUSSION and CONCLUSION: The prevalence of MTHFR C677T and A1298C heterozygous polymorphism was found to be high.There was no significant difference between patients with stroke according to the presence of predisposing risk factors in terms of prothrombotic mutations. It was determined that the protombotic gene mutations did not affect the risk of stroke according to the presence of stroke risk factors.
\end{abstract}

Keywords: Young stroke, ischemic, prothrombin gene mutation.

\section{İSKEMIK STROK GEÇIREN GENÇ HASTALARDA PROTROMBOTIKK GEN MUTASYONLARI:} KLINIIK TECRÜBEMİ

\section{ÖZET}

GİRIŞ ve AMAÇ: Genç erişkinlerde inmenin etiyolojik değerlendirilmesi farklı incelemeleri içermektedir. Geniş etiyolojik araştırmalarla nedeninin tespitine göre tedavinin şekillendirilmesi, özellikle rekurrens riskinin de düşürülmesi açısından önemlidir. Genç inme tanısı ile izlenmiş olgularda protrombotik gen mutasyonlarının incelenmesi, predispozan risk faktörü olan ve olmayan olguların gen mutasyonları açısından varlığı ve karşılaştırılması amaçlanmıștır.

YÖNTEM ve GEREÇLER: İskemik stroke geçirmiş 18-45 yaş arası hastalar alındı. Özgeçmişlerindeki inme risk faktörleri ile protein C (PC), protein S (PS), antitrombin 3 (ATIII), homosistein, antinükleer antikor (ANA) antikardiolipin (AKA) testleri ve Faktör V G1691A Leiden (FVL), Protrombin G20210A, Metilentetrahidrofolat redüktaz (MTHFR) C677T ve A1298C genetik test sonuçları kaydedilmiştir.

BULGULAR: Çalışmaya toplam 120 (64 E, 56 K) hasta alındı. Hastaların yaş ortalaması $38 \pm 6.9$ idi. İnme risk faktörü 77

\footnotetext{
Corresponding author: Zeynep Özözen Ayas, MD. Eskișehir City Hospital, Department of Neurology, Eskișehir, TURKEY

Telephone: +902226114000 E-mail:zozozen@hotmail.com

Received: 01.03.2019 Accepted: 19.06.2019

This article should be cited as following: Özözen Ayas Z, Aks oy Gündoğdu A, Bölük A. Prothrombotic gene mutations in young patients with ischemic stroke:

our clinical experience. Turkish Journal of Cerebrovascular Diseases 2019; 25 (2): 94-100. doi: 10.5505/tbdhd.2019.90267
} 
hastada belirlenirken, 43'ünde herhangi bir risk faktörü saptanmadı. En sık 44 (\% 36.7) hastada sigara içiciliği ve 23 (19.2 \%) hastada hipertansiyon kaydedildi. 13 hastada FVL polimorfizmi heterozigot saptandl. Protrombin polimorfizmi 11 heterozigot, 1 homozigot, MTHFR C677T polimorfizmi 56 heterozigot, 10 homozigot, MTHFR A1298C polimorfizmi 45 heterozigot, 13 homozigot olarak saptandı. Hiperhomosisteinemi 66, ATIII eksikliği 16, PC eksikliği 19, PS eksikliği 19 hastada tespit edildi. İnme için predispozan risk faktörü olan ve olmayan grupta protrombotik gen heterozigot ve homozigot polimorfizmleri açısından anlamlı bir farklılık saptanmamıştır. Ayrıca bu iki grup arasında hiperhomosisteinemi sıklığı, ATIII, PC, PS eksikliği sıklı̆̆ı, ANA pozitifliği sıklığında anlamlı bir farklılık saptanmamıștır.

TARTIŞMA ve SONUÇ: Çalışmamızda özellikle MTHFR C677T ve A1298C heterozigot polimorfizm sıklığı yüksek oranda bulunmuştur. Genç inmeli hastalar predispozan risk faktörü olup olmamasına göre protrombotik mutasyonlar açısından karşılaştırıldığında anlamlı bir fark görülmemiştir. Protombotik gen mutasyonlarının inme risk faktörleri varlığına göre inme riskini etkilemediği saptanmıștır.

Anahtar Sözcükler Genç stroke, iskemik, protrombin gen mutasyonu.

\section{INTRODUCTION}

Stroke is a significant cause of morbidity and mortality, of which incidence increases with age. The incidence of stroke in young adults under forty-five years was reported as 3.4-12.1/1000.000 (1-4). While the age, gender, race and family history are unmodifiable risk factors among etiological reasons, the hypertension, diabetes mellitus, heart disease, hypercholesterolemia, smoking, carotid stenosis are definitive modifiable factors. However, no reason can be identified in $23-25 \%$ of the patients despite all examinations (5). The etiologic evaluation of the young patients group with stroke includes more different examinations compared to elderly patients group. It was reported that while classical atherosclerotic risk factors are prominent after 35 years of age, cardioembolism, dissection, non-atherosclerotic vasculopathy and prothrombotic conditions are important in patients aged 15-35 years (6). It is important to adjust treatment depending on the determination of causes by more comprehensive etiologic researches, in terms of reducing the risk of recurrence as well. The rate of hypercoagulability in young patients with stroke is $6-15 \%(7,8)$. The role of prothrombotic gene mutations, especially known to be associated with venous thrombosis, in the pathogenesis of arterial ischemic stroke remains controversial. Evaluation of Factor $\mathrm{V}$ G1691A Leiden (FVL), prothrombin G20210A gene, methylenetetrahydrofolatreductase (MTHFR) genes, protein $\mathrm{C}(\mathrm{PC})$, protein $\mathrm{S}$ (PS), antithrombin 3 (ATIII), fibrinogen, activated protein $C$ resistance (APCR), homocysteine antinuclear antibody (ANA) anticardiolipin antibody (ACA) tests in qualified laboratories and their being accessible in all centers for young patients with stroke are diffcult in clinical practice, but provide a broad perspective. In our study, the frequency of all prothrombotic gene mutations taking place in all patient groups with and without predisposing risk factor for young patients with stroke, and their roles on stroke formation were discussed in the light of literature.

\section{MATERIAL AND METHODS}

In this study, the files of 3512 patients who admitted to our hospital's neurology polyclinic or adult emergency department and who were diagnosed with acute arterial ischemic stroke with results of anamnesis, neurological examination and radiological imaging (BT and/or MRI) were retrospectively examined. 120 out of these patients from 18 to 45 years who underwent ischemic stroke (64 male, 56 female) were included in the study. Patients with sinus venous thrombosis, intracranial hemorrhage and subarachnoid hemorrhage were excluded from the study.

The risk factors for stroke in the patients' history such as hypertension, diabetes mellitus, coronary heart disease, history of stroke, atrial fibrillation, smoking, migraine, hyperlipidemia, valve replacement, hyperthyroidism/hypothyroidism, history of abortion, vasculitic disease, blood disease, chronic alcohol intake and use of oral contraceptive (OCD) drug were recorded. For patients under forty-five years who underwent young ischemic stroke, routine electrocardiography, electrocardiogram, carotid-vertebral doppler ultrasonography, FVL, prothrombin G20210A, MTHFR C677T and A1298C genetic analyzes, PC, PS, ATIII, fibrinogen, homocysteine, ANA, AKA tests were performed for further etiologic research. The stroke etiology of the patients were made according to modified Trial of Org 10172 in Acute Stroke Treatment (TOAST) classification (9). 
A sample was taken from the patients following the information form taken from them. Genomic DNA samples obtained using DNA isolation kit from 2-3 ml peripheral venous blood samples taken into EDTA tubes were used.

In this study, real time PCR method was used for the analysis of FVL, prothrombin G20210A, MTHFR C677T, MTHFR A1298C mutations. DNA samples of the patients were studied with Lightcycler-Factor V Leiden Mutation Detection Kit (Roche, Germany). A mixture was prepared with all PCR components and $15 \mu \mathrm{l}$ from this mixture was distributed to the capillaries. $5 \mu \mathrm{l}$ of the DNA samples of the patients were added to such PCR mixture. PCR was performed on Light Cycler 2.0 real time PCR device and the results were evaluated according to Melting Curve.

The statistical analysis of the data was made using SPSS 22.0 software. Mean, standard deviation, median, lowest, highest, frequency and ratio values were used in the descriptive statistics of the data. The compliance of data with normal distribution was analyzed using Kolmogorov Smirnov Test. For the analysis of quantitative independent data, chi-square test, and if conditions for chi-square test could not be ensured Fischer test was used. Odds ratios and $\mathrm{p}$ values were calculated in 95\% confidence interval of the variables. Statistical significance level was taken as $\mathrm{p}<0.05$.

\section{RESULTS}

A total of 120 patients, 64 male (53.3\%) and 56 female (46.7\%) who were diagnosed as acute ischemic stroke aged 18-45 years were included in this study. The average age of the patients was 3806.9. While evaluating risk factors for stroke etiology, the risk factors were identified in 77 patients, whereas no risk factor was found in 43 patients. One risk factor was found in $44(36.7 \%)$ patients, two in $24(20 \%)$ patients, three in 5 $(4.2 \%)$ patients, and four in $4(3.3 \%)$ patients. The most common history of the patients was smoking in $44(36.7 \%)$ patients and hypertension in 23 $(19.2 \%)$ patients. In addition, it was observed that $8(6.7 \%)$ patients had a history of stroke, $8(6.7 \%)$ patients had hematological hypercoagulation disorders, 7 (5.8\%) patients had diabetes mellitus, $7(5.8 \%)$ patients had a history of recurrent miscarriage, $6(5.0 \%)$ patients had coronary artery disease, $4(3.3 \%)$ patients had migraine, $3(2.5 \%)$ patients had hyperlipidemia, $3(2.5 \%)$ patients had hyperthyroidism, $3(2.5 \%)$ patients had chronic alcohol intake, $2(1.7 \%)$ patients had cardiac valve replacement, $2(1.7 \%)$ patients had vasculitic disease, $1(0.8 \%)$ patient had atrial fibrillatin, 1 $(0.8 \%)$ patient had hypothyroidism and $1(0.8 \%)$ patient used OCD (Table I). In our study in which patients with cerebral sinus venous trombosis were excluded, no patient had a history of venous thromboembolism. According to TOAST classification, while 6 patients had atherothrombosis, 9 patients had cardioembolic, 27 patients had lacunar infarct, 18 patients had other identified etiologies, 60 patients had infarcts of unknown origin.

Table I. The number and percentage of risk factors of patients.

\begin{tabular}{|l|c|c|}
\hline Gender & $\begin{array}{c}\text { Number } \\
\text { (n) }\end{array}$ & $\begin{array}{c}\text { Percentage } \\
\text { (\%) }\end{array}$ \\
\hline Female & 56 & 46.7 \\
\hline Male & 64 & 53.3 \\
\hline HT & 23 & 19.2 \\
\hline DM & 7 & 5.8 \\
\hline CVD & 8 & 6.7 \\
\hline CAD & 6 & 5.0 \\
\hline AF & 1 & 0.8 \\
\hline HL & 3 & 2.5 \\
\hline Valvular replacement & 2 & 1.7 \\
\hline hyperthyroidism & 3 & 2.5 \\
\hline hypothyroidis & 1 & 0.8 \\
Abortion III & 7 & 5.8 \\
Vasculitic disease & 2 & 1.7 \\
Hematologic risk factor & 8 & 6.7 \\
Migraine IV & 4 & 3.3 \\
\hline Smoking I & 44 & 36.7 \\
\hline Alcohol & 3 & 2.5 \\
\hline OCD & 1 & 0.8 \\
\hline Number of risk factor & 44 & 36.7 \\
\multicolumn{1}{|c|}{} & 24 & 20.0 \\
\hline
\end{tabular}

HT: Hypertension, DM: Diabetes mellitus, CVD: Cerebrovascular disease, CAD: Coronary artery disease, AF: Atrial fibrillation, HL: Hyperlipidemia, OCD: Oral contraceptive.

The heterozygous mutant was detected in 13 (10.8\%) patients with FVL polymorphism, whereas no homozygous mutation was detected in any patient. Prothrombin polymorphism was detected as heterozygous mutant in $11(9.2 \%)$ patients and as homozygous mutant in 1 patient (0.8\%). MTHFR C677T polymorphism was evaluated as heterozygous mutant in $56(46.7 \%)$ patients and homozygous mutant in $10(8.3 \%)$ patients. MTHFR A1298C polymorphism was found as heterozygous mutant in $45(37.5 \%)$ patients and homozygous 
mutant in $13(10.8 \%)$ patients (Table II). Hyperhomocysteinemia (HS) was detected in 66 (55.0\%) patients, ATIII deficiency in 16 (13.3\%) patients, PC deficiency in $19(15.8 \%)$ patients and PS deficiency in 19 (15.8\%) patients. Hyperfibrinogenemia was detected in 10 (8.3\%) patients. $1(0.8 \%)$ patient was found AKA positive, and $16(13.3 \%)$ patients were found ANA positive.

Table II. The frequency of prothrombic gene polymorphism.

\begin{tabular}{lccc}
\hline & $\begin{array}{c}\text { Normal } \\
(\%)\end{array}$ & $\begin{array}{c}\text { heterozygous } \\
(\%)\end{array}$ & $\begin{array}{c}\text { homozygous } \\
(\%)\end{array}$ \\
\hline $\begin{array}{l}\text { Prothrombin } \\
(\mathrm{G} 20210 \mathrm{~A})\end{array}$ & $108(90 \%)$ & $11(9.2 \%)$ & $1(0.8 \%)$ \\
$\begin{array}{l}\text { Factor V Leiden } \\
(\mathrm{G} 1691 \mathrm{~A})\end{array}$ & $107(89.2 \%)$ & $13(10.8 \%)$ & 0 \\
$\begin{array}{l}\text { MTHFR } \\
(\mathrm{C} 677 \mathrm{~T})\end{array}$ & $54(45 \%)$ & $56(46.7 \%)$ & $10(8.3 \%)$ \\
$\begin{array}{l}\text { MTHFR } \\
\text { (A1298C) }\end{array}$ & $62(51.7 \%)$ & $45(37.5 \%)$ & $13(10.8 \%)$ \\
\hline
\end{tabular}

No significant difference was found in terms of FVL, prothrombin, MTHFR C677T, MTHFR A1298C heterozygote and homozygous polymorphisms in the group with and without predisposing risk factors for stroke. $(\mathrm{p}=0.687, \mathrm{p}=0.899, \mathrm{p}=0.353$, $\mathrm{p}=0.266$ ) (Table III). In addition, no significant difference was observed between these two groups in terms of HS ratio, PC deficiency rate, PS deficiency rate, ATIII deficiency rate and ANA positivity. $(\mathrm{p}=0.369, \mathrm{p}=0.673, \mathrm{p}=0.920, \mathrm{p}=0.634$, $\mathrm{p}=0.332$ ) (Table III).

Table III. Prothrombotic gene polymophrism and hypercoagulopathy values in patients with or without predisposing risk factor for stroke.

\begin{tabular}{|c|c|c|c|c|}
\hline & & $\begin{array}{c}\text { risk } \\
\text { factor }(+)\end{array}$ & $\begin{array}{c}\text { risk } \\
\text { factor }(-)\end{array}$ & $\mathrm{p}$ \\
\hline $\begin{array}{l}\text { Factor V Leiden } \\
\text { (G1691A) }\end{array}$ & heterozygous & 4 & 9 & 0.687 \\
\hline Prothrombin & heterozygous & 4 & 7 & 0.899 \\
\hline$(\mathrm{G} 20210 \mathrm{~A})$ & homozygous & 0 & 1 & \\
\hline MTHFR & heterozygous & 19 & 37 & 0.353 \\
\hline$(\mathrm{C} 677 \mathrm{~T})$ & homozygous & 3 & 7 & \\
\hline MTHFR & heterozygous & 19 & 26 & 0.266 \\
\hline (A1298C) & homozygous & 6 & 7 & \\
\hline \multicolumn{2}{|c|}{ Hyperhomocysteinemia } & 26 & 40 & 0.369 \\
\hline \multicolumn{2}{|c|}{ PC deficieny } & 6 & 13 & 0.673 \\
\hline \multicolumn{2}{|l|}{ PS deficiency } & 7 & 12 & 0.920 \\
\hline \multicolumn{2}{|l|}{ ATIII deficiency } & 8 & 8 & 0.204 \\
\hline \multicolumn{2}{|l|}{ ANA } & 4 & 12 & 0.332 \\
\hline
\end{tabular}

Prior to stroke, 4 patients (2 valve replacement, 1 patient $\mathrm{AF}, 1$ advanced heart failure) had a history of using warfarin sodium, however 2 patients had an effective INR value. Coagulopathy tests were performed by stopping anticoagulant therapy for 2 weeks before sample collection in genetic analysis period in order to obtain optimal results from the tests of these 4 patients.

\section{DISCUSSION}

Studies showed that the incidence of stroke in young patients is between 3.4-12.1/100.000 (1-4). In our study, the stroke rate in patients between 18 and 45 years was found as $3.4 \%$.

It was reported that young stroke is more common in men (10). On the other hand, there are also studies indicating that gender does not cause any difference $(11,12)$. Our study found that male gender is at the forefront with a rate of $53.3 \%$.

No underlying cause can be detected in some patients despite all etiologic examinations. In a comprehensive study with 3331 patients who underwent ischemic stroke for the first time, no cause was found at a rate of $39.6 \%$ (13). In our study, risk factors were identified in 77 (64.2\%) patients and no risk factors were identified in 43 (35.8\%) patients. All causes need to be investigated, even in the presence of a significant risk factor. Because, it is known that the risk of thrombosis is increased in the presence of multiple risk factors. In our study, one risk factor was found in 44 patients, two in 24 patients, three in 5 patients, and four in 4 patients. Smoking was shown to increase blood fibrinogen levels, increase platelet aggregation and hematocrit, and thus increase blood viscosity. Smoking is an independent risk factor for ischemic stroke, leading to carotid artery sclerosis (14). Hypertension increases the formation of atherosclerosis by producing endothelial dysfunction and increasing the permeability of endothelium to lipoproteins (15). In a study in which 1008 young stroke patients were evaluated, dyslipidemia, smoking and hypertension were reported as the most common risk factors (2). In another study, smoking and dyslipidemia were determined as the most common causes. In our study, smoking (36.7\%) and hypertension (19.2\%) were identified as the most common risk factors. However, dyslipidemia was found as $2.5 \%$ only. Excessive alcohol intake also increases the risk of stroke and related deaths (16). In our study, it was found that only $1(0.8 \%)$ patient underwent stroke at young age due to chronic and excessive alcohol intake. 
The causes of stroke in young people vary compared to the general population. Therefore, all etiologic examinations should be performed in detail even in the presence of a risk factor.

FVL mutation is the most common prothrombotic risk factor resulting in increased thrombin (17). In one study, FVL mutation was found at a rate of $9.3 \%$ and as heterozygous mutant only in young strokes (18). Similarly, only FVL heterozygous mutant $(10.8 \%)$ was detected in our study, whereas no homozygous mutation was detected. FVL and prothrombin G20210A mutations were proposed to increase ischemic stroke in combination with clinical risk factors for arterial ischemic diseases. In this study, FVL mutation was found as $8.3 \%$ only in ischemic stroke patients with heterozygous polymorphism, whereas it was found as $2.5 \%$ in the control group having no stroke clinic with similar clinical risk factors (19). On the other hand, in this study, it was found that FVL mutation increased the risk of stroke in women and in people without stroke risk factors, in men and compared to those with risk factors (19). In our study, it was found that there was no significant difference in terms of mutation according to the presence of predisposing risk factors in young stroke patients. This suggests that FVL polymorphism does not affect the risk of stroke according to the presence of ischemia stroke risk factor.

Prothrombin G20210A mutation raises blood plasma prothrombin levels, leading to hypercoagulability and imposes 2-4 times higher risk for venous thrombosis (20). Although this polymorphism is well characterized for venous thrombosis, arterial vascular disease remains unclear, especially in young adults with ischemic stroke. In a study, heterozygous prothrombin G20210A mutation was reported to be a significant predisposition for sinus venous thrombosis in patients with sinus venous thrombosis $(14.9 \%)$ and arterial ischemic stroke (4.95\%) compared to the control group $(2.97 \%)$, but not significant in arterial ischemic stroke (21). In another study, prothrombin G20210A mutation was reported to be associated with ischemic stroke in young adults younger than 55 years, and have a stronger association, especially among those with earlyonset stroke below 42 years of age (22). However, in our study, prothrombin G20210A polymorphism was found to be heterozygous in $11(9.2 \%)$ patients and homozygous in $1(0.8 \%)$ patients and no significant association was found with ischemic risk factor. The results were thought to be consistent with heterozygous polymorphism, which is also likely to be seen in healthy individuals. It was suggested that prothrombin G20210A polymorphism did not affect stroke risk according to the presence of ischemia stroke risk factor.

Some mutations in the MTHFR gene inactivate the enzyme and predispose to hyperhomocysteinemia and cardiovascular and cerebrovascular diseases. In one study, they found MTHFR C677T polymorphism, 34.5\% heterozygous and $10.4 \%$ homozygous mutation in stroke patients (23). In a study they conducted in Korean society, they suggested that MTHFR C677T and A1298C polymorphisms may be risk factors for ischemic stroke (24). In a study conducted by Ucar et al. on patients who underwent ischemic stroke in Black Sea region of Turkey, the MTHFR 677TT homozygous mutant genotype frequency was found as $6.6 \%$ in patient group and $3.3 \%$ in control group (25). The frequency of homozygous MTHFR C677TT mutation in the Turkish population was reported to be 5-9\% (26). In our study, MTHFR C677T heterozygous polymorphism was found to be significantly higher (46.7\%). The frequency of heterozygous polymorphism in healthy individuals may also show an ethnic difference. In our study, homozygous polymorphism rate was $8.3 \%$. However, no significant difference was found when the patients with and without risk factors for predisposing ischemic stroke were compared. It was suggested that MTHFR C677T polymorphism does not affect the stroke risk according to the presence of ischemia stroke risk factor. Although MTHFR C677T polymorphism that was found in young stroke group in a study was found in a high rate in our study, no significant difference was found when compared with healthy control group (27). In addition, Li et al. found that MTHFR C677T mutation increased high serum homocysteine levels and showed that homozygous MTHFR 677TT mutation was associated with thrombotic stroke in Chinese people (28). In our study, no significant difference was found in the group with and without HS in terms of MTHFR C677T distribution.

In a study, it was reported that homozygous mutant genotype ratio was found to be highest in MTHFR A1298C polymorphism in the examination of prothrombotic gene mutations in young stroke patients (18). Similarly, in our study, MTHFR A1298C gene was found to be a homozygous mutant at the highest level. MTHFR A1298C polymorphism was found to be heterozygous in 45 
(37.5\%) patients and homozygous in 13 (10.8\%) patients. No significant difference was found when the patients with and without risk factors for stroke were compared in terms of MTHFR A1298C polymorphism. It was suggested that MTHFR A1298C polymorphism does not affect the stroke risk according to the presence of ischemia stroke risk factor. In our study, no significant difference was found in the group with and without HS in terms of MTHFR A1298C distribution.

The prevalence of PC, PS and ATIII in ischemic stroke varies up to $23 \%$ in different studies (29). In a large meta-analysis, reports for the cases and studies regarding PS, PC, ATIII deficiencies due to ischemic stroke were collected and it was reported that the relationship of PC with arterial stroke was poor, PS was moderate, and ATIII was rare (30). PC deficiency has sometimes been associated with arterial ischemic stroke. In a published study, PC deficiency was found $11.5 \%(6 / 52)$ in young stroke patients (31). Similarly, in our study, PC deficiency was detected in 19 (15.8\%) patients.

Hereditary PS deficiency is an independent risk factor for venous thromboembolism, but its role in ischemic stroke is controversial $(32,33)$. In a study, hereditary was found to be the primary cause of thrombosis in a family diagnosed with PS mutation (34). PS deficiency is often associated more than PC deficiency in arterial ischemic stroke. However, conflicting reports limit the credibility of this union. In a comprehensive meta-analysis, this deficiency was reported to be $13,8 \%(5 / 36), 23 \%$ (8/35), 19\% (19/98) in patients under 45 years, and $6 \%(4 / 66)$ in patients 60 years and below (20). In the contrary, numerous studies show a less frequent association of stroke and PS deficiency (33). In the Iowa cohort study, only 1 out of 329 stroke patients aged 15-45 years were found to have PS deficiency, whereas in a Swedish study of 107 patients aged 18-44 years, only one had PS deficiency (30). In one study, PS deficiency was found as $28.8 \%(15 / 52)$ in young patients (31). In our study, PS deficiency was found in 19 (15.8\%) patients and no patients had a history of venous thromboembolism. ATIII deficiency was found as $4.5 \%(3 / 66)$ in ischemic stroke patients under 65 years of age (35). This was found in our study as $13.3 \%(16 / 120)$.

The limitations of our study were that it was a retrospective, single-center study and a healthy control group was lacking. The role of prothrombotic gene mutations in ischemic stroke will be evaluated in more detail by examining the control group with similar risk factors.

It is thought that prothrombotic gene mutations in young ischemic stroke patients do not affect the risk of stroke according to the presence of ischemia stroke risk factor.

As conclusion, the heterozygous polymorphism frequency especially for MTHFR C677T and A1298C was found at high levels in our study, No significant difference was found when young ischemic patients were compared in terms of prothrombotic mutations according to the presence of predisposing risk factors. In this study, it was found that prothrombotic gene mutations do not affect stroke risk according to the presence of stroke risk factors.

\section{REFERENCES}

1. Ghandehari K, Moud ZI. Incidence and etiology of ischemic stroke in Persian young adults. Acta Neurol Scand. 2006; 113(2): 121-124.

2. Putaala J, Metso AJ, Metso TM, Konkola N, Kraemer Y, Haapanemi E, Kaste M, Tatlisumak T. Analysis of 1008 consecutive patients aged 15 yo 49 with first-ever ischemic stroke: the Helsinki young stroke registry. Stroke. 2009; 40(4): 1195-1203.

3. Jacobs BS, Boden-Albala B, Lin IF, Sacco RL. Stroke in the young in the northern Manhattan stroke study. Stroke. 2002; 33(12): 2789-2793.

4. Groppo E, De Gennaro R, Granieri G, Fazio P, Cesnik E, Granieri E, Casetta I. Incidence and prognosis of stroke in young adults: a population-based study in Ferrara, Italy. Neurol Sci 2012; 33(1): 53-58.

5. Öncel Ç, Bir LS, Oğuzhanoğlu A, Eröz Ö. Etiology of cerebrovascular disease in young adults. J Neurol Sci 2009; 26(1): 12-17.

6. Bendixen BH, Posner J, Lango R. Stroke in young adults and children. Curr Neurol Neurosci Rep 2001; 1(1): 54-66.

7. Kristensen B, Malm J, Carlberg B, Stegmayr B, Backman C, Fagerlund M, Olsson T. Epidemiology and etiology of ischemic stroke in young adults agde 18 to 44 years in Northern Sweden. Stroke 1997; 28: 1702-1709.

8. Leys D, Bandu L, Henon H, Lucas C, Mounier-Vehier F, Rondepierre P, Godefrov O. Clinical outcome in 287 consecutive young adults (15 to 45 years) with ischemic stroke. Neurology 2002; 59: 26-33.

9. Adams HP Jr, Bendixen BH, Kappelle LJ, Biller J, Love BB, Gor-don DL, et al. Classification of subtype of acute ischemic stro- ke. Definitions for use in a multicenter clinical trial. TOAST. Trial of ORG 10172 in Acute Stroke Treatment. Stroke 1993; 24: 35-41.

10. Dash D, Bhashin A, Pandit AK, Tripathi M, Bhatia R, Prasad K, Padma MV. Risk factors and etiologies of ischemic stroke in young patients: a tertiary hospital study in North India Journal Stroke 2014; 16: 173-177.

11. Ji R, Schwamm LH, Pervez MA, Singhal AB. Ischemic stroke and transient ischemic attack in young adults: risk factors, diagnostic yield, neuroimaging, and thrombolysis. JAMA Neurol 2013; 70(1): 51-57. 
12. Özer İș, Sorgun MH, Rzayev S, Kuzu M, Tezcan S, Yılmaz V, Ulukan Ç, Çotur H, Rawandi A, Işıkay CT. Etiologic subtypes, risk factors, and outcomes of acute ischemic stroke in young patients. Turk J Neurol 2015; 21: 159-164.

13. Yesilot Barlas N, Putaala J, Waje-Anderson U, Vassilopoulo S, Nardi K, Odier C, et al. Etiology of first-ever ischaemic stroke in European young adults: the 15 cities young stroke study. Eur J Neurol 2013; 20(11): 1431-1439.

14. Hergens MP, Lambe M, Pershagen G, Terent A, Ye W. Smokeless tobacco and the risk of stroke. Epidemiology 2009; 20(3): 471.

15. Goldstein L.B, Adams R, Becker K, Furberg CD, Gorelick PB, Hademenos G, et al. Primary prevention of ischemic stroke: a statement for healthcare professionals from the stroke council of the American Heart Association. Stroke 2001; 32(1): 280-299.

16. Mazzaglia G, Britton AR, Altmann DR, Cheret L. Exploring the relationship between alcohol consumption and non-fatal and fatal stroke: A systematic review. Addiction 2001; 96: 1743- 56.

17. Bertna MR. Molecular risk factors for thrombosis. Thromb Haemost 1999; 82(2): 601-609.

18. Öztürk KH, Özgöz A, İçduygu FM, Soysal Y, Küsbeci ÖY, İmirzalığlu N, et al. Prothrombotic gene polymorphisms in young patients with cerebrovascular accident J Clin Anal Med 2013; 4(4): 273-276.

19. Eterovic D, Titlic M, Culic V, Zadro R, Primorac D. Lower contribution of factor $\mathrm{V}$ leiden or G202104 mutations to ischemic stroke in patients with clinical risk factros: pairmatched case-control study. Clin Appl Thromb Hemost 2007; 13(2): 188-193.

20. Beye A, Pindur G. Clinical significance of factor $V$ Leiden and prothrombin G20210A-mutataions in cerebral venous thrombosis- comparison with arterial ischemic stroke. Clin Hemorheol Microcirc 2017; 67(3-4): 261-266.

21. Bank I, Libourel EJ, Middeldorp S, Van Pampus EC, Koopman MM, Hamulyak K, et al. Prothrombin 20210A mutation: a mild risk factor for venous thromboembolism but nit for arteriel thromboitc disease and pregnancy-related complications in a family study. Arch Intern Med 2004; 164: 1932-1937.

22. Jiang B, Ryan KA, Hamedani A, Cheng Y, Sparks MJ, Koontz D, et al. Prothrombin G20210A mutation is associated with young-onset stroke: the genetics of early-onset stroke study and meta-analysis. Stroke 2014; 45(4): 961-967.

23. Lopaciuk S, Bykowska K, Kwiecinski H, Mickielewicz A, Czlonkowska A, Mendel T, et al. Faktör V Leiden, prothrombin gene G20210A variant and MTHFR C677T genotype in young adults with ischemic stroke. Clin Appl Thromb Hemost 2001; 7(4): 346-350.
24. Han IB, Kim OJ, Ahn JY, Miao L, Wu DF, Aung LH, et al. Association of methylenetetrahydrofolate reductase (MTHFR 677C ?T and 1298 A 20) polymorphisms and haplotypes with silent brain infarction and homocysteine levels in a Korean population. Yonsei Med J 2010; 51: 253260.

25. Ucar F, Sonmez M, Ovali E, Ozmenoglu M, Karti SS, Yilmaz M, et al. MTHFR C677T polymorphism and its relation to ischemic stroke in the Black Sea Turkish population, Am J Hematol 2004; 76(1): 40-43.

26. Akar N, Akar E, Dalgin G, Sozuoz A, Omurlu K, Cin S. Frequency of factor V (1691 G-A) mutation in Turkish population. J Thromb Haemost 1997; 78(6): 1527-1529.

27. Djordjevic V, Stankovic M, Brankovic-Sreckovic V, Rakicevic $\mathrm{L}$, Damnjanovic T, et al. Prothrombotic genetic risk factors in stroke: a possible different role in pediatric and adult patients. Clin Appl Thromb Hemost 2012; 18(6): 658-661.

28. Li Z, Sun Li, Zhang H, Liao Y, Wang D, Zhao B, et al. Elevated plasma homocysteine was associated with hemorrhagic and ischemic stroke, but Methylenetetrahydrofolat Reductase gene C677T polymorphism was a risk factor thrombotic stroke: a multicenter case-control study in China. Stroke 2003; 34(9): 2085-2090.

29. Bushnell CD, Goldenstein LB. Diagnostic testing for coagulopathies with ischemic stroke. Stroke 2000; 31(12): 3067-3078.

30. Moster M. Coagulopathies and arterial stroke. Journal of Neuro-Ophthalmology. 2003; 23(1): 63-71.

31. Chatterjee T, Gupta N, Choudhry VP, Behari M, Saxena R, Ashraf MZ. Prediction of ischemic stroke in young Indians: is thrombophilia profiling a way out? Blood Coagul Fibrinolysis 2013: 24(4); 449-453.

32. Ten Kate MK, Plattel M, Mulder R, et al. PROS1 analyses in 87 pedigrees with hereditary protein $\mathrm{S}$ deficiency demostrates striking genotype-phenotype associations. Hum Mutant 2008; 29: 939-947.

33. Soare AM, Popa C. Deficiencies of protein C, S, and antithrombin and factor $\mathrm{V}$ Leiden and the risk of ischemic strokes. J Med Life. 2010; 3: 235-238.

34. Wang ZH, Zhao ZJ, Xu K, Sun GB, Song L, Yin HX, Chen XQ. Hereditary protein $\mathrm{S}$ deficiency leads to ischemic stroke. Mol Med Rep. 2015; 12(3): 3279-3284.

35. Vrethem M, Dahle C, Lindahl T, Ernerudh J. Association between deficiency of free protein $\mathrm{S}$ and anticardiolipin antibodies in patients 65 years of age with acute ischemic stroke and TIA. Eur J neurol. 1998; 5(5): 491-497. 